\title{
REPRODUCTIVE POLITICS AND POPULISM: PENTECOSTAL RELIGION AND HEGEMONY IN THE PHILIPPINES
}

\author{
GIOVANNI MALTESE
}

Assistant Professor of Religious Studies and Global Christianity, Faculty of Humanities, University of Hamburg

\begin{abstract}
Reproductive politics is the locus classicus for studying the entanglement of religion with politics and lawmaking processes in the Philippines. Although 25 percent of the total population participates in the Pentecostal movement, there is virtually no comprehensive work that studies this movement's attitudes about reproductive health. In this article I analyze Pentecostals' attitude on reproductive health vis-à-vis recent studies that depict the movement as religious populism. I investigate the interests and exclusions that Pentecostals' keywords and narratives, as well as recent scholarship on Pentecostalism, conceal. I first provide a genealogical reconstruction of the debate on reproductive health in the Philippines. Second, I provide an overview of the religious landscape and discuss Pentecostal's attitudes toward reproductive health while demonstrating that their rhetorical positions cannot be understood apart from hegemonic struggles and their entanglement with local and global discourse. Third, I draw theoretical and methodological implications for the study of Pentecostalism, politics, and lawmaking processes in the Philippines. Finally, I conclude by showing the relationship between Pentecostalism in the Philippines and the broader study of religion and politics, including making and implementing law.
\end{abstract}

KEYWORDS: Pentecostalism, Philippines, reproductive politics, populism, hegemony

\section{INTRODUCTION}

Reproductive politics is the locus classicus for studying the entanglement of religion with politics and lawmaking processes in the Philippines. In December 20I2, then president Benigno Aquino signed into law the House Bill on Responsible Parenthood and Reproductive Health (RA I0354), which seemed to have ended a decade-long struggle in the Philippines. The most controversial aspects of the law included (I) the creation of rights to knowledge about and access to methods of family planning and (2) the requirement that employees in public health, social work, and education disseminate appropriate information and make contraceptive devices available. The latter requirement included sanctions on those who did not comply with the duty of implementing comprehensive sex-education in schools, which involved providing information about so-called modern-that is, artificial-methods of birth-control. ${ }^{\text {I }}$

I Philippine Legislators' Committee on Population and Development PLCPD, RA 10354 A Primer on the Reproductive Health Law (Quezon City: Philippine Legislators' Committee on Population and Development, 
However, there was more at stake than just questions of family planning and sexual morality. The struggle over RA I0354 was about national identity and the hegemonic role of the Catholic hierarchy. In fact, right after the proclamation of the law, several pro-life groups challenged it before the Supreme Court, contesting its constitutionality. As a result, the implementation of the law on reproductive health was stalled and the status quo ante was declared. ${ }^{2}$

How did Pentecostals position themselves in this hegemonic struggle? Although 25 percent of the total population participates in the Pentecostal movement (which has an ambivalent relationship with conservative Evangelicalism), there is virtually no comprehensive work that studies this movement's attitudes about reproductive health. At best, there are some studies that give a side glance at Catholic Charismatics and co-opt the Charismatics into a narrative that favors the official Catholic position. In this article, I analyze Pentecostals' attitudes in the debates on reproductive health, asking two questions: How did influential key figures rationalize their attitudes? Which plausibilities, keywords, and narratives did they draw on? My findings contradict the current state of research on Philippine Pentecostalism, which describes the movement as "religious populism" with an intrinsic leaning toward authoritarianism, religious intolerance, and an escapist approach to political issues, along with an indifference toward questions of social justice. ${ }^{3}$ The detailed contextualization of articulations about reproductive health marks the critical thrust of this article. I ask what the interests and exclusions are that Pentecostals' and Evangelicals' keywords and narratives conceal. I also offer a "genealogical" account of the contemporary discourse on reproductive health ${ }^{4}$ that brings to the fore the ideology and exclusions undergirding current scholarship on Pentecostalism in the Philippines. Human rights scholar Abdullahi An-Na'im argues in his forthcoming work that there is a need to "decolonize" so-called progressive discourses on justice and rights. 5 This discursive decolonization begs for a theoretical framework capable of addressing the conditions for the possibility of, on the one hand, Pentecostals' concrete use of specific articulation and rhetoric and, on the other, the categories employed by scholars of Pentecostal studies that have led them to overlook important dimensions of Pentecostals' political engagement. I submit that political theorist Ernesto Laclau's theory of hegemony offers such a frameworknamely, one that theorizes the notion of populism and religion underlying the current knowledge production about Pentecostalism and helps to decolonize it. Thus, I first give a genealogical reconstruction of the debate on reproductive health. Second, I give an overview of the religious landscape, introduce the main Pentecostal players and their entanglement with Evangelicalism, and

20I3), 4-6, 9-II, http:/www.plcpd.org.ph/wp-content/uploads/20I4/o8/A-primer-on-the-Reproductive-HealthLaw.pdf; Karen Boncocan, "RH Bill Finally Signed Into Law," Inquirer.net (blog), December 28, 20I 2, http://newsinfo.inquirer.net/33I395/gonzales-aquino-signed-rh-bill-into-law; Esperanza Cabral, "Reproductive Health Law in the Philippines," Journal of the ASEAN Federation of Endocrine Societies, 28, no. I (2013): 26-27.

2 Cabral, "Reproductive Health Law in the Philippines," 28-29; Buena Bernal, "SC Declares RH Law Constitutional," Rappler, April Io, 20I4, http://www.rappler.com/nation/54946-supreme-court-rh-lawconstitutional; Eric Marcelo O. Genilo, "The Catholic Church and the Reproductive Health Bill Debate: The Philippine Experience," Heythrop Journal 55, no. 6 (2014): I044-55; Jose Mario C. Francisco, "Letting the Texts on RH Speak for Themselves: (Dis)Continuity and (Counter)Point in CBCP Statements," Philippine Studies: Historical and Ethnographic Viewpoints 63, no. 2 (201 5): 223-46.

3 Christl Kessler and Jürgen Rüland, Give Jesus a Hand! Charismatic Christians: Populist Religion and Politics in the Philippines (Quezon City: Ateneo de Manila University Press, 2008), I90-97.

4 Michel Foucault, "Nietzsche, Genealogy, History," in Language, Counter-Memory, Practice: Selected Essays and Interviews, ed. Sherry Simon (Ithaca: Cornell University Press, 1977), 139-64; Judith Butler, Undoing Gender (New York: Routledge, 2004), 21 5-16.

5 Abdullahi A. An-Na'im, "Decolonizing Human Rights: From State-Centric to People-Centered" (unpublished manuscript). 
discuss their attitudes toward reproductive health while demonstrating that their rhetorical positioning cannot be understood apart from hegemonic struggles and their entanglement with local and global discourses. Third, I draw theoretical and methodological implications for the study of Pentecostalism, politics, and lawmaking processes in the Philippines. Finally, I conclude by showing the relationship between Pentecostalism in the Philippines and the broader study of religion and politics, including making and implementing law.

\section{A GENEALOGY OF REPRODUCTIVE HEALTH IN THE PHILIPPINES}

At the time when RA I0354 was signed into law, the meaning of the term reproductive rights among the majority of the population was quite new. Until the late 2000 , reproductive rights was understood mainly as related to issues of women's individual health and sexuality. Over time, the idea of reproductive health came to encompass issues related to national economics, social ethics, poverty, and development politics. In the subsections below, I trace the career of this signifier, reproductive health, in the context of a Catholic predominance in the Philippines.

\section{Reproductive Policy under Ferdinand Marcos (1965-1986) and Corazon Aquino (I986-I992)}

The controversy about government programs aimed at regulating the reproductive behavior of the population in a systematic way-especially the poorer segments of society-goes back to the r96os. From the beginning, it was linked to questions of access to artificial birth control methods, which the Catholic hierarchy has always opposed. ${ }^{6}$ At the same time, it was linked to economic and existential questions. While colonial powers welcomed high fertility rates among the natives of their lands -it produced workers and fighting forces - the situation changed in the second half of the twentieth century. In the wake of the so-called decolonization and during the Cold War, the same colonial states started programs of population control premised on arguments about overpopulation and into which they poured large amounts of funds. Postcolonial studies have criticized this development discourse as a neocolonial policy to keep the former subjugated people dependent on foreign resources and to cement global asymmetries. From this point of view, the discourse of overpopulation was an ideology that promoted population control as means to reduce poverty, concealing the actual problems: unequal distribution of resources and global injustice. ${ }^{7}$

In the Philippines, the first significant population-reduction program can be traced back to President Ferdinand Marcos. Important pillars of that program were the provision of artificial

6 Renato Manaloto, "The Philippine Reproductive Health Legislation: Politics beyond Metaphysics," Asian Bioethics Review 6, no. 4 (20I4): $343-58$, at 345; see also Sharmila Parmanand, "Mapping the Path to Philippine Reproductive Rights Legislation: Signs of Progress amidst Obstacles," Social Transformations: Journal of the Global South 2, no. I (20I4): 6I-80; Jennifer Leighn Sta.Ana, "The Role of Catholicism on Reproductive Health Care Policies in Mexico and the Philippines" (master's thesis, Georgetown University, 20Io), https://repository.library.georgetown.edu/bitstream/handle/I0822/553393/sta.AnaJennifer.pdf?sequence=I.

7 Shalini Randeria, "Fortpflanzung selbstverantwortlich gestalten" [Taking responsibility for reproduction] in Wenig Kinder-viel Konsum? Stimmen zur Bevölkerungsfrage von Frauen aus dem Süden und Norden [Few childrenmuch consumption? Voices on population issues from women living in the south and in the north], ed. Helen Zweifel (Basel: Brot für alle, I994), I04-08, at I04-05; Shalini Randeria, "The Crisis of Developmentalism: Some Theses on Culture, Political Process and Population Policies," in Development Models and World Views, ed. Eckhard Deutscher, Thomas Jahn, and Bernard Moltmann (Frankfurt: Societats, I996), 78-92. 
contraceptives and the introduction of policies that aimed at reducing the fertility rate, implemented by the newly created Commission on Population. While these efforts were based on the rationale that poverty, industrial backwardness, and high fertility rates are causally related, they were, at the same time, a move against communist and Muslim separatist insurgents who drew their main constituency from families with many children. The main sponsor of this program was the United States, which had secured significant economic and military privileges as conditions for granting the Philippines independence. But Marcos's US policy was not able to overcome the resistance of the Catholic Church, which rejected "modern family planning." Under President Corazon Aquino, who came to power through the support of the Catholic Bishops' Conference of the Philippines, the program was stopped. ${ }^{8}$

Since the 400-year colonization by the Spanish, the Catholic Church has maintained large cultural and political influence in the Philippines and has been perceived to be a social conservative force, supporting traditional economic and political elites despite a remarkable Catholic left associated with liberation theology and led by local intellectuals. 9 The developments of the twentieth century did not change this. ${ }^{\mathrm{IO}}$ Catholicism has, therefore, been criticized for naturalizing male-dominated heteronormative hierarchy, equating womanhood with motherhood, and reducing sexuality to the procreation mandate. This influence confined women's agency to the domestic sphere. A further result of this naturalization was that women and individuals who diverge from or question this ideal of family and society are virtually excluded from full participation in the public sphere and in political processes. ${ }^{\text {II }}$

\section{Reproductive Policy under Fidel Ramos (I992-1998) and Joseph Estrada (I998-200I)}

Against this background, the presidency of Fidel Ramos, the first Protestant president, can hardly be overestimated. His reproductive policy represents a break in the history of traditional dominance by Catholic Philippine elites close to the Catholic Bishops' Conference of the Philippines. This

8 Thanks to US funds, the budget of the Commission on Population was twice that of the Ministry of Social Services, notwithstanding that the former was a subdivision of the Ministry of Social Services. Maria Dulce F. Natividad, "Reproductive Politics, Religion and State Governance in the Philippines" (PhD dissertation, Columbia University, 20I2), 40-44.

9 Enrique N. P. Leviste, "In the Name of Fathers, In Defense of Mothers: Hegemony, Resistance, and the Catholic Church on the Philippine Population Policy,” Philippine Sociological Review 64, no. I (2016): 5-44, at 32.

Io This influence was temporarily weakened when the United States took colonial control from Spain, but it was quickly regained during and after the Japanese occupation and the social changes related to industrialization programs, national independence, and urbanization in the second half of the twentieth century. Emergence of world ecumenism in the I950s and the neo-Evangelical mission movement did not change this. Catholicism was never seriously threatened by Protestantism in the Philippines as it was in Latin America. The Cold War and the social changes helped the hierarchy strengthen its hegemonic role, and the Catholic Bishops' Conference of the Philippines, in reinterpreting parts of its teachings after Vatican II, institutionalized the Pentecostal-Charismatic renewal rather than quenching it. Kessler and Rüland, Give Jesus a Hand!, 52-86; Giovanni Maltese, Pentekostalismus, Politik und Gesellschaft in den Philippinen [Pentecostalism, politics and society in the Philippines] (Baden-Baden: Ergon, 2017), 62-67.

I I Carolina S. Ruiz Austria, "The Church, the State and Women's Bodies in the Context of Religious Fundamentalism in the Philippines," Reproductive Health Matters I2, no. 24 (2004): 96-I03; Natividad, "Reproductive Politics," 4-Io. The fact that the Catholic Church's teachings on sexuality and the concept of family and gender underlying them have been contested from within Catholicism by liberal theologians did not deter the critics, especially given that conservative forces do still exert a strong influence on politicians and are still predominant within the Catholic Bishops' Conference of the Philippines. Leviste, "In the Name of Fathers," $32,35-36$. 
correlates with a new period in the history of the country's women's rights activism, which has been one of the fiercest antagonists to the predominant Catholic hierarchy. Although the Ramos administration espoused a neoliberal economic policy, it provided leftist feminists an environment that helped them organize, making space for the movement to begin voicing its demands through parliamentary action.

There were two important developments in creating this new space for feminist activism in the Philippines. First, a new discourse on reproductive health was launched at the Cairo International Conference on Population in I994, transforming issues previously vilified as population control into a matter of health policy, making space for this discourse in Philippine politics for the first time. $^{\text {I2 }}$ Second, following a global trend, Ramos transferred control over population policies to the Department of Health. Yet this occurred virtually unnoticed by large parts of society because Ramos operated with enough discretion so as not to anger the Catholic hierarchy. In the Philippine context, these two developments led to a peculiar constellation of effects of the Cairo conference: while on the global stage the Cairo conference was attacked by leftist feminists as being about neither women's rights nor antipoverty, but as masquerading a neoliberal agenda, the invention of reproductive health discourse and its bureaucratization offered leftist groups in the Philippines some new space to strengthen their position against the Catholic Church. In sum, the Philippine reception to reproductive health was limited to intellectuals and a few lobby groups. ${ }^{\mathrm{I}}$ Under Joseph Estrada's administration, these circumstances remained stable for women's activism. ${ }^{\mathrm{I}}$

\section{Reproductive Policy under Gloria Macapagal-Arroyo (200I-2010)}

The situation changed when Gloria Macapagal-Arroyo became president after the ousting of Estrada. The support of the Catholic hierarchy and a large contingent of business elites for Macapagal-Arroyo were the main factors for the regime change, ${ }^{15}$ and she implemented conservative family and economic policies that favored the interests of those who had supported her. ${ }^{16}$ Women's-rights activists came under remarkable pressure, but they found an ally in the lesbian and gay networks. In 2002, Macapagal-Arroyo introduced a national strategic plan for natural family planning, implemented under her health minister, Manuel Dayrit, a well-known Opus Dei member, in close collaboration with the Catholic Charismatic organization Couples for Christ. ${ }^{17}$ The plan promoted only "natural family planning," ${ }_{18}$ while all other methods were dubbed as "anti-God, anti-family and anti-Filipino." I9 In reaction, the various women's-rights groups, which had formerly worked independently, increased their efforts to form a congress lobby and

I2 Natividad, "Reproductive Politics," 39-40, 42; Sandra D. Lane, "From Population Control to Reproductive Health: An Emerging Policy Agenda," Social Science and Medicine 39, no. 9 (1994): 1303-34. See also Marilen J. Dañguilan, Women in Brackets: A Chronicle of Vatican Power and Control (Pasig City: Philippine Center for Investigative Journalism, I997).

I3 Natividad, "Reproductive Politics," 7-8, 39-44.

I 4 Natividad, 7, 4I; Jonathan Tseung-Hao Chow, "Religion, Politics and Sex: Contesting Catholic Teaching and Transnational Reproductive Health Norms in the Contemporary Philippines" (PhD dissertation, University of California, 20II), I37-4I, http://search.proquest.com/docview/I 525990023/A 59D 2E 25 EoI 74AD 3 PQ/7; Patricio N. Abinales and Donna J. Amoroso, State and Society in the Philippines (Lanham: Rowman \& Littlefield, 2005), 266-76.

I 5 Abinales and Amoroso, State and Society in the Philippines, 277-79.

I6 Chow, "Religion, Politics and Sex," I43.

I7 Natividad, "Reproductive Politics," I 66-69.

I8 Austria, "The Church, the State and Women's Bodies," 99.

I9 Natividad, "Reproductive Politics," 7, 35. 
draft house bills on reproductive health. ${ }^{20}$ As reproductive health stood for sexual and reproductive self-determination for women and was framed in terms of individual rights, the bills had "women" as the main referral. ${ }^{21}$ Conservative Catholic groups activated a highly moralizing discourse to isolate those who promoted the bills, declaring the bills to be against God, against the Filipino people, and against the constitution. ${ }^{22}$ None of the women's rights bills were successful. House members, mostly male, would simply not attend the hearings and thus boycotted the whole process. Yet this failure led to the establishment of the Reproductive Health Advocacy Network, which was soon to become the most vocal promoter of progressive reproduction policies and of liberal discourse on issues of sexuality. Additionally, the Reproductive Health Advocacy Network became the fiercest antagonist of the Catholic Bishops' Conference of the Philippines. ${ }^{23}$

\section{Reproductive Policy under Benigno Aquino (2010-20I6)}

With the presidential candidacy of Benigno Aquino in 2010 , debates about reproductive health gained large attention from the media, as Aquino stood for a more progressive reproductive policy. Central to his campaign, which aimed at mobilizing common people, was the narrative of causality between population growth and mass poverty, and his staunch anticorruption platform directed against political competitors hailing from the traditional elite families. The debates on reproductive health reached a new peak in $20 \mathrm{II}_{\mathrm{I}} \mathrm{I} 2$, when a new House bill was presented in Congress. As president, Aquino transferred the responsibility of scrutinizing the bill to the Committee on Population and Family Relations. Before, that task had always been the responsibility of the Committee on Health and the Committee on Women. ${ }^{24}$ Poverty was explained to be a result of overpopulation and birth control was therefore the solution. At the same time, Aquino, in a position statement titled "Responsible Parenthood," assured the public that the bill was neither unconstitutional nor anti-Catholic, but pro-life. ${ }^{25}$ Using popular phrases such as "sacredness of human life," he tried to close ranks with the Catholic Bishops' Conference of the Philippines. ${ }^{26}$

Thus, reproductive health issues were now officially a question of development policies. Congress members who would usually not attend the house hearings on reproductive health to boycott the process would now expose themselves to the charge of being indifferent to the plight of the

20 Austria, "The Church, the State and Women's Bodies," Ioo-oI; Natividad, "Reproductive Politics," $34-35$.

2 I Erika M. Sales, "People, President and the Pulpit: The Politics of the Reproductive Health Bill of the Philippines" (master's thesis, Erasmus University Rotterdam, 20I2), I8, http://thesis.eur.nl/pub/13037/.

22 Austria, "The Church, the State and Women's Bodies," I00-02; Natividad, "Reproductive Politics," 73. This discourse was based on the arguments of conservative Catholic groups such as Abayfamilya, which claimed that even contraceptives such as birth control pills were abortifacient, and "[i]n reversal of earlier findings by the previous administration's Health Secretary, the Bureau of Food and Drugs issued a decision ... which stated that the 1987 Constitution defined pregnancy as beginning at 'the moment of fertilization.'” Austria, "The Church, the State and Women's Bodies," 98. Reproductive health bills were thus condemned as anti-constitutional.

23 Austria, "The Church, the State and Women's Bodies," Io0-oI; Natividad, "Reproductive Politics," 34-35.

24 Sales, "People, President and the Pulpit," I8.

25 Benigno S. Aquino III, "Responsible Parenthood: The Five-Point Position on Responsible Parenthood of President Benigno S. Aquino III,” Official Gazette of the Republic of the Philippines, 20I 2, http://www.officialgazette.gov. $\mathrm{ph} / \mathrm{responsible-parenthood/.} \mathrm{The} \mathrm{position} \mathrm{statement} \mathrm{affirmed} \mathrm{that} \mathrm{the} \mathrm{law} \mathrm{prohibited} \mathrm{abortion,} \mathrm{that} \mathrm{it} \mathrm{protected} \mathrm{life}$ "beginning at conception and ending with natural death," and that "natural family planning ... would be presented as equally available." See Sales, "People, President and the Pulpit," I 5-I6, 33-35.

26 Moreover, romanticizing the past, he tried to present his politics as compatible with both the public mainstream and the predominant discourse that "Filipino identity and culture" were "by nature religious" (meaning Catholic). Austria, "The Church, the State and Women's Bodies," roo. 
poor. However, leftists rejected the overpopulation narrative as an ideology intended to divert from unequal distribution of wealth. ${ }^{27}$ Hence, the term reproductive health came to represent something new in the public discourse. As noted above, before this shift, reproductive health stood mainly for issues related to the health and sexuality of women, framed in terms of individual and personal rights. From this point on, however, it stood for antipoverty politics and inclusive economic growth. This corresponded to a reinvention of the idea of reproductive health. At the same time, it shifted the identity markers. Before, being pro-reproductive health implied being pro-women's rights and eo ipso being progressive and left. After this, reproductive health could also stand for a new chain of equivalence constituted by the keywords neoliberal, conservative, and neocolonial. ${ }^{28}$ As a result of this shift, a number of leftists who had supported reproductive health aligned themselves with the anti-reproductive health camp.

Aquino's move toward a new reproductive health legislation triggered a new tide of resistance that consolidated reproductive health as a name for broader power claims and hegemonic struggles. ${ }^{29}$ When, in 2014, the Supreme Court declared the reproductive health law, RA I0354, constitutional, it was only a pyrrhic victory, as eight passages had to be deleted from the official text, chief among them those containing the sanctions for not making knowledge and devices on family planning available. This brought great damage to the progressives in the pro-reproductive health camp, who had already been hit by the defection of several left-leaning supporters of reproductive health who had aligned themselves with the anti-reproductive health camp. To them, supporting the final draft of the bill-which de facto was a compromise paper-would be a capitulation to Aquino's neoliberalism. ${ }^{30}$

\section{PENTECOSTAL ARTICULATION OF REPRODUCTIVE HEALTH IN CONTEXT}

How did Pentecostals position themselves in this precarious power play? The following subsections provide a brief overview of the religious landscape and then a discussion of Pentecostal articulations drawn from interviews conducted during fieldwork between 2012 and 2015 and from brochures and position papers issued during this time.

\section{Pentecostal Players and the Philippine Religious Landscape}

The Philippines has been called "the only Christian nation of all Asia": 80.6 percent of the population is Roman-Catholic; 9.5 percent identify as non-Catholic (mainly Protestant) Christian, 5.6 percent identify as Muslim, and 4.3 percent identify as "other or nonreligion" (the majority of

27 Sales, "People, President and the Pulpit," I 5-1 8, 33-35.

28 This observation is based on extensive fieldwork between 2010 and 20I4, when I conducted interviews with representatives of various political and ideological camps. See Maltese, Pentekostalismus, 43-5 I, 465-60o.

29 Rodrigo Duterte, then vice mayor of Davao made the contents of the bill mandatory, which was consistent with his anti-Catholic stance. In contrast, in Ayala Alabang local government acts banning pharmacies from selling condoms were enforced. Sales, "People, President and the Pulpit," I6.

30 Bernal, "SC Declares RH Law Constitutional”; Benedikt Seemann, "President Aquino's Last Mile: An (Early) Assessment of His Presidency," Country Reports (Manila: Konrad-Adenauer-Stiftung, 2015), https://www.kas. de/web/philippinen/laenderberichte/detail/-/content/praesident-aquinos-letzte-meile-I; see also Marc Jayson Cayabyab, "Supreme Court Derailed RH Law, Lagman Laments," Inquirer.net, January I3, 20I7, http://newsinfo.inquirer.net/862049/supreme-court-derailed-rh-law-lagman-laments. 
whom as adherents of so-called ethnic religions). $3^{\text {I }}$ Between 19 and 44 percent of the population participates in the Pentecostal movement with the Catholic Pentecostals (or Charismatics) having two times the number of adherents as do their Protestant counterparts. ${ }^{32}$ Among the Catholic Pentecostals, the most important groups are El Shaddai and Couples for Christ. Protestant Pentecostals can be subdivided in two major groups: the so-called classical Pentecostal churches affiliated with the Philippine Council of Evangelical Churches and the so-called independent Pentecostals affiliated with the Philippines for Jesus Movement, also usually referred to as Evangelicals. This movement was launched in 1983 by Eduardo "Eddie" Villanueva, a Marxist turned Evangelist, who in 2004 and 2010 ran for presidency and for senator in 2013.33

\section{Catholic Pentecostals}

Both El Shaddai and the Couples for Christ were established in the I980s. While Couples for Christ was initiated by Jesuits, El Shaddai was founded by Mike Velarde, an entrepreneur turned televangelist. The charismatic renewal within the Catholic Church started as a movement that was rather critical of the hierarchy. Both groups have supported various administrations, despite employing a rhetoric that criticized the hierarchy's links with politicians and condemned liberation theology as too political. ${ }^{34}$ Of the two groups, El Shaddai has been perceived as the greater embarrassment by the hierarchy. This was mainly due to Velarde's self-understanding as a televangelist and healer and his alignment with President Estrada, but also to El Shaddai's constituency, which unlike Couples for Christ, comes from the lower classes. After the ousting of Estrada in 200I, El-Shaddai founder Velarde found himself isolated. Couples for Christ congregations, in turn, were staunch supporters of Macapagal-Arroyo. When Macapagal-Arroyo chose Couples for Christ as her main partner, Velarde founded Buhay Hayaan Yumabong (Let Life Prosper), a political party whose aim was to promote traditional Catholic morals and family values. 35

3 I National Statistics Office, Philippines in Figures 2014 (Manila: Republic of the Philippines: National Statistic Office, 20I4), 27. Other statistics count 84 percent Catholics, I I percent Muslims, and 5 percent non-Catholic Christian groups, including ethnic religions and atheists. Bureau of Democracy Human Rights and Labor, “2013 International Religious Freedom Report” (US Department of State, 20I3), I-2, http://www.state.gov/documents/organization/222373.pdf.

32 Pew Research Center, "Spirit and Power: A ro-Country Survey of Pentecostals" (Washington, DC: Pew Research Center, October 5, 2006), 4, http://www.pewforum.org/2006/Io/o5/historical-overview-of-pentecostalismin-philippines/; Kessler and Rüland, Give Jesus a Hand!, 93; Todd M. Johnson, "Counting Pentecostals Worldwide," Pneuma 36, no. 2 (2014): 265-88, at 283-87.

33 Maltese, Pentekostalismus, 62-66. To highlight the extent to which these groups represented a threat to the political status quo, it is useful to note that, beginning with the I990s, Mike Velarde and Villanueva were both under surveillance by international intelligence services, see Maltese, Pentekostalismus, 26-30, IоI, I20. A third group is the so-called Oneness Pentecostals, whose trinity/triunity theology differs from the former, but who, nevertheless, are generally discussed in close relationship with Evangelical Pentecostals. To date, no influential umbrella organization has managed to unite Oneness Pentecostals in a significant way; rather, they work as single churches, often in lose affiliation with Philippines for Jesus. For the sake of brevity, I focus only on the first two groups. For a discussion of Oneness Pentecostals and reproductive health, see Maltese, Pentekostalismus, 487-9г. For a recent historical account of Oneness Pentecostalism in the Philippines, see Johnny Loye King, "Spirit and Schism: A History of 'Oneness Pentecostalism' in the Philippines” (PhD dissertation, University of Birmingham, 20I7).

34 For a brief overview of the links between Catholic hierarchy and political elites, see Leviste, "In the Name of Fathers," I6-I9.

35 Kessler and Rüland, Give Jesus a Hand!, 78; Roberto E. N. Rivera, "The Couples for Christ: Suborganizational Framing and Sociopolitical Mobilization in the Catholic Charismatic Renewal" (PhD dissertation, University of 
Notwithstanding their tensions with the Catholic Bishops' Conference of the Philippines, Catholic Pentecostals supported its anti-reproductive health position. Due to competition for adherents and influence in political circles, El Shaddai and Couples for Christ started to outpace each other in their work to oppose reproductive health. ${ }^{36}$ They organized rallies and seminars where "modern family planning" was defined as promoting a "culture of death," contraceptive pills were oftentimes explained to be cancerous, and the intrauterine device, or IUD, was described as an abortifacient. During the election campaign, they printed placards that displayed the proreproductive health candidates under the heading "Death Team," contrasting them with the church-leaning candidates, dubbed "Life Team." 37 The objective was to stage one's own group as more actively life-affirming than the other and thus gain influence among both the Catholic hierarchy and the largely conservative population. $3^{8}$

\section{Older, So-Called Classical Pentecostals}

The so-called classical Pentecostal denominations became visible in the I950s as daughter churches of US denominations. Accordingly, they soon became members of the Philippine Evangelical Council of Churches. 39 Their identity marker was a rhetoric of exclusive focus on spiritual issues against the Catholic and mainline Protestant churches, which they dubbed worldly and political.4०

Unlike Catholics, evangelical Pentecostals have always espoused less conservative sexual ethics. Certainly, abortion (which, however, had never been part of the final reproductive health law) and promiscuity were taboo. This was in full conformity with the attitude of the popular mainstream (as discussed in relation to Aquino's position in "Responsible Parenthood"). Yet, to avoid further stigmatization by the Catholic majority society, they never made much ado about it. In their counseling and teachings on marriage and family, however, they were firm defenders of artificial family planning, and they actively encouraged couples to get information about contraceptive methods, even to

Notre Dame, 2008), 62-65, 238-39; Katharine L. Wiegele, Investing in Miracles: El Shaddai and the Transformation of Popular Catholicism in the Philippines (Honolulu: University of Hawai'i Press, 2005), 2-5, 50, 56; Katharine L. Wiegele, "Politics, Education and Civil Participation: Catholic Charismatic Modernities in the Philippines," in Global Pentecostalism in the 21st Century, ed. Robert W. Hefner (Bloomington: Indiana University Press, 2013), 223-250, at 242-43; Maltese, Pentekostalismus, 62-66, I 23-37.

36 In 2013 I participated in various anti-reproductive health rallies organized by Couples for Christ and El Shaddai in Negros, Luzon, and Mindanao and spoke with a number of representatives about the competition within Catholic Pentecostalism.

37 On the culture of life/death rhetoric, see Julius Bautista, "Church and State in the Philippines: Tackling Life Issues in a "Culture of Death," Sojourn: Journal of Social Issues in Southeast Asia 25, no. I (2010): 29-53; Genilo, "The Catholic Church and the Reproductive Health Bill Debate," ı050.

38 Jesuit scholar Eric Genilo notes that the few Catholic academics who articulated their dissent from the bishops' position had only limited impact outside their immediate university circles. Most notably among them were fourteen faculty members based at the Jesuit-run Ateneo de Manila University, who, citing Catholic social teachings, argued "that the proposed law was consistent with the promotion of the common good" and released a statement titled "Catholics Can Support the RH Bill in Good Conscience," and forty-five faculty members of the De la Salle University, run by the Brothers of the Christian School, who issued a similar position paper titled "The RH Bill is Pro-Life." Genilo, "The Catholic Church and the Reproductive Health Bill Debate," I05I.

39 The Philippine Council of Evangelical Churches was founded in 1965 as a conservative counterpart to the recently established mainline Protestant National Council of Churches, which in turn has strong links to the World Council of Churches. Until the I 980 s, statistics would subsume them under the labels fundamentalist or conservative Evangelicals. David B. Barrett, ed., World Christian Encyclopedia: A Comparative Study of Churches and Religions in the Modern World, AD I900-2000 (New York: Oxford University Press, I982), 562-68. Kessler and Rüland, Give Jesus a Hand!, 66-67. 
the point of offering financial support for those who wanted to undergo sterilization. This apparently nonpolitical attitude goes back to their traditional rhetoric of being solely "concerned with spiritual things." It was a rhetoric inherited by US evangelical missionaries, who were advised to keep out from politics if they wanted to operate in the country. Thus, Pentecostals were perceived as being apolitical or quietist at best. What was overlooked or ignored, however, was that their actual practice differed from this, especially when it came to local politics. ${ }^{4 \mathrm{I}}$ When the debates peaked in 2012, also due to Aquino's reinvention of the meaning of reproductive health, the older Pentecostals followed the policy of not politicizing reproductive health. No public statement was issued by the denomination's leaders on reproductive health, and requests for the denominations' official position were denied. Yet the older Pentecostal denominations generally referred to a statement issued by the Evangelical Council, which they had signed as members. ${ }^{42}$ During the Macapagal-Arroyo presidency the council had kept a low profile in order not to lose its privileged position; Macapagal-Arroyo had appointed the Evangelical Council's top leader as spiritual advisor, which helped him to outmaneuver Villanueva whose movement represented the council's main rival in the competition for adherents and influence in the public sphere. Now, with Benigno Aquino as president, things had changed. At the peak of the reproductive health debates, the Evangelical Council released a position paper that was both pro-reproductive health and progovernment policy. Under the headline "Evangelical Churches Re-echo Strong Support for Rh Bill," it stated, "When He [God] commanded ... 'Be fruitful and increase' ... He gave it to a world population of two. Now that the world population has escalated to seven billion ... We restate: the RH Bill is pro-life, pro-development and pro-poor." 43

The Evangelicals' pro-reproductive health statement, which the older Pentecostal denominations subscribed to, followed a threefold objective. First, it served to disprove the image of being otherworldly in a fanatical biblicist way, ${ }^{44}$ as it staged the Catholic reading of Genesis one as being a literalist exegesis without any cultural contextualization and thus as being fundamentalist. Second, it served to dispel the image of being indifferent to social problems as it explicitly mentions the poverty issue. Third, and most importantly, it served to court the Aquino government, which in a manner typical for Philippine politics had turned its back on actors known to be close to the

4 I See Maltese, Pentekostalismus, 478-83, 486-87.

42 The mainline Protestant churches, known to be decidedly vocal on political issues, also issued statements that contained an outspoken critique of the neoliberal narrative of "overpopulation" and "poverty" employed by President Aquino. See "Fullness of Life For All: A Continuing Commitment-A Statement in Support of the RH Bill," NCCP: National Council of Churches in the Philippines (blog), October I2, 20I I, http://nccplibrary.blogspot. com/20II/05/cpbc-statement-in-support-of-rh-bill.html (drafted by the Convention of Philippine Baptist Churches); United Church of Christ in the Philippines, "UCCP: A Church Response to the Responsible Parenthood, Reproductive Health, and Population and Development Act (House Bill 4244), " August 23 , 20 I I. The Evangelical Council's statement, in contrast, expressed its unreserved support for the Aquino government. Further, and in contrast to mainline Protestant statements that ended in ecumenical-conciliar spirit toward "our Catholic brethren" (as in the abovementioned UCCP paper), the Evangelical Council's statement contained a clear anti-Catholic thrust.

43 Philippine Council of Evangelical Churches, "Evangelical Churches Re-Echo Strong Support for Rh Bill," August 5, 20I2, https://rhbillresourcepage.wordpress.com/201 2/08/05/evangelical-churches-re-echo-strong-supportfor-rh-bill/.

44 See Catholic Bishops' Conference of the Philippines, Catholic Guidelines on Fundamentalism: Hold Fast to What Is Good (Manila: Catholic Bishops' Conference of the Philippines, I989); Nicholas O. Fort, ed., Exploring the New Religious Movements in the Philippines: Documents of the National Consultation of the New Religious Movements in the Philippines, October I8-20, 1988 (Quezon City: Commission on Evangelism and Ecumenical Relations, National Council of Churches in the Philippines, I989); Leonardo N. Mercado, "Muslim and Christian Fundamentalism in the Philippines," Philippiniana Sacra 33, no. 97 (I998): 5-20. 
previous administration, such as the Evangelical Council's top leader, Efraim Tendero, who had been one of Macapagal-Arroyo's spiritual advisors.45 In fact, not only had Aquino favored Philippines for Jesus leader Eddie Villanueva against the Evangelical Council, but he had also appointed his son Joel Villanueva a cabinet member. ${ }^{46}$

Thus, Evangelical Pentecostals were able to keep their tradition of being focused on spiritual rather than worldly things (which is a political gesture) and yet fend off the perception of being indifferent to social issues. At the same time, given the pro-administration rhetoric of the position paper, they advertised themselves to the new administration as potential partners.

\section{Newer, So-Called Independent Pentecostals}

As a reaction to the US-leaning Pentecostal churches affiliated with Evangelical Council, a new branch of evangelical Pentecostals emerged by the late I970s. These were churches founded by Filipino pioneers who had broken with their former US denominations to launch their own ministries and thus called themselves "independent." Soon, the success of the native-run independent churches outperformed those of the older Pentecostals, who accused the younger churches of being syncretistic. Most prominent among leaders of these new independent churches was Eddie Villanueva. A Marxist activist turned evangelist, he founded the Philippines for Jesus Movement in 1983 after establishing a flourishing megachurch. From the beginning, it was conceived as a patriotic, US-critical alternative to the Evangelical Council drawing a large number of churches and ministries into the movement. In 1986, Villanueva launched Intercessors for the Philippines, the Philippines for Jesus Movement's teaching and mobilization arm created to "raise an awareness for the moral, economic and political issues of the country." 47 When Villanueva founded the Bangon Pilipinas Party (or Philippines Arise) in a bid for the presidency in 2004, Intercessors for the Philippines was instrumental in running Villanueva's election campaign. ${ }^{8}$ Although Villanueva's campaign was unsuccessful, his loss to Macapagal-Arroyo triggered the establishing of another influential suborganization of the Philippines for Jesus Movement, called Movement for National Transformation. When Villanueva ran for a second time in 20I0, the Movement for National Transformation conducted a nationwide cadre program among Pentecostal churches. Defeated again, this time by Aquino, Villanueva ran for the Senate in 2013 - also unsuccessfully. By now, however, Intercessors for the Philippines and the Movement for National Transformation had already started to differ on a number of issues, including questions of leadership, the role of reproductive health in political mobilization, and how to organize mass support for preferred candidates.

Like Protestants associated with the Evangelical Council, Pentecostals linked to Philippines for Jesus were traditionally in favor of contraceptives. Unlike the Evangelical Council, however, they were vocal about it. Since its beginning, Philippines for Jesus was thoroughly political. In order

45 See Marichu A. Villanueva, "Hostage Crisis My Defining Moment, GMA,” Philstar Global (blog), July 24, 2004, http://www.philstar.com/headlines/258659/hostage-crisis-my-defining-moment- $\% \mathrm{C}_{2} \% 97 \% \mathrm{C}_{2} \%$ Aogma.

46 Amita Legaspi, "New TESDA Chief Aims to Improve Agency’s Image,” GMA News Online (blog), July I4, 20Iо, http://www.gmanetwork.com/news/news/nation/ı96086/new-tesda-chief-aims-to-improve-agency-s-image/story/.

47 Wonsuk Ma, "Philippines for Jesus Movement," in The New International Dictionary of Pentecostal and Charismatic Movements, ed. Stanley M. Burgess and Gary B. McGee, rev. and exp. (Grand Rapids: Zondervan, 2002), 988; Wonsuk Ma, "Philippines," in Burgess and McGee, The New International Dictionary of Pentecostal and Charismatic Movements, $20 \mathrm{I}-07$.

48 This came after Villanueva had established a minority party list called Citizen's Battle Against Corruption and had won one seat in Congress when his son Joel was elected a representative. See Maltese, Pentekostalismus, I34-50. 
to distinguish themselves from the established mainline Protestants-who were perceived to be intellectual and all too rational-they still employed a rhetoric of "spirituality," deploying phrases such as "we pray for a transformation" and "only the gospel can change the course of history," when asked for a statement. Yet, as has already become clear from Villanueva's political activities and from those of Intercessors for the Philippines and the Movement for National Transformation, their practice was anything but escapist. Back in 2010 , Villanueva was among the few presidential candidates whose platform included a decidedly pro-reproductive health policy. This was embedded in campaign slogans such as "revolution of righteousness," "emancipating the people" and "empowering the people" against the perceived Catholic elites. 49 It was further embedded in his alliance with Nur Misuari, the founder of the first armed Islamic secession movement, and his alliance with leftist groups. $5^{\circ}$ However, Villanueva drew his main constituency from the middle and lower classes, known for their conservative attitudes on moral issues. Thus, he needed to articulate his anti-status quo politics in a way that was compatible with the larger public. Just as Aquino's "Responsible Parenthood" would in 2012, he routinely distanced himself from abortion and staged himself as the candidate of a radical center. At the same time, he candidly challenged the neoliberal reproductive health ideology promoted by his presidential competitor, Aquino: "the so-called "population explosion' is not the cause of poverty; rather, it is the effect of poverty ... the real ... issue, is ... equitable sharing of resources." ${ }^{5} \mathrm{I}$

In 20I3, when Villanueva ran for the Senate, he toned down slightly his critique against Aquino: the latter had given Villanueva's son a cabinet position, which Villanueva did not want to jeopardize. Furthermore, Villanueva was hoping to coopt the administrations party machinery on the local level for his own campaign. ${ }^{52}$ Villanueva's moderate turn was criticized by Pentecostals within

49 Bangon Pilipinas BP, “Official Website of Bangon Pilipinas," Bangon Pilipinas, 2009, http://www.bangonpilipinas. ph/; Paterno II Esmaquel, “JIL's Bro Eddie Calls for 'Revolution of Righteousness,” Rappler, October 26, 20I3, http://www.rappler.com/nation/42262-bro-eddie-jesus-is-lord-35th-anniversary.

50 Sophia Dedace, "Misuari Endorses Bro. Eddie, Runs as His Sulu Gubernatorial Bet," GMA News Online (blog), February II, 20I0, http://www.gmanetwork.com/news/story/I 83694/news/nation/misuari-endorses-bro-eddieruns-as-his-sulu-gubernatorial-bet; Maltese, Pentekostalismus, 174-75. Even the Marxist international policy group Focus on the Global South stated in 2010 "Of the candidates, [Brother] Eddie's platform on governance is the most elaborate, and also has concrete ideas on how to proceed and some timeline." Jenina Joy Chavez, "Rating the Candidates: Prosecution as Platform," in Transitions: Focus on the Philippines 2010 Yearbook, ed. Clarissa Militante (Quezon City: Focus on the Global South-Philippines, 20II), 27-30, at 29; Pagbabago! People's Movement for Change PPMFC, "Voting for Change: Will the May 2010 Elections Deliver?," Arkibong Bayan (blog), May 4, 20I0, http://www.arkibongbayan.org/2010/2010-04Mayo6-Elections2010/ Makabayan.htm (website no longer available).

5I Eddie Villanueva and Bangon Pilipinas BP, "Stand of Bangon Pilipinas Party on the RH Bill," Facebook, October 5, 20I0, http://www.facebook.com/note.php?note_id=439007676195.

52 A close look, however, shows that Villanueva did not abandon his critique of Aquino's neoliberal course; rather, Villanueva disguised his critique by diverting his attacks on the anti-reproductive health campaigns of the Catholic Bishops' Conference of the Philippines and stressing that present politics was still controlled by a few Catholic dynasties exploiting the population. In this way, he hit the Aquino administration indirectly and even admitted his sympathies with communist New People's Army guerillas who waged an armed struggle against the government; albeit he maintained that violent revolutionary actions would not make the Philippines a better place: "But you cannot blame the leftist people ... Which I used to be one of them you know, I was just ... my mental ability is too limited, that's why ... ok let's fight, let's unite the masses and spread the ideology of National Democratic Revolution.” Eddie Villanueva, interview by the author, May Iо, 2013, Tagbilaran. Further, and unlike other so-called religious candidates, he rarely employed biblical argumentations in public interviews but instead rationalized his politics along progressive ideas of social reform. Instead of wholly condemning the intrauterine device, as Catholic candidates did, he gave it conditional support. He stated that "as long as there is no new insight" regarding the question when exactly the device becomes operative in the beginning of human life process 
his party. In interviews with me, he noted that influential cadres accused him of becoming a compromiser, given that his son was now part of the oppressive class. For them, Aquino's discourse on reproductive health was a capitulation to the "neo-imperial dictate of the West" aiming at "decimating the Filipino population." Thus, the same antagonistic lines between radical and pragmatic leftists which disaggregated the pro-reproductive health camp were present within Pentecostal members of Villanueva's party.

A remarkable shift also took place among the leadership of Villanueva's Philippines for Jesus Movement. Until 2OII-I2 both teaching arms, Intercessors for the Philippines and the Movement for National Transformation, did not themselves issue statements on reproductive health, but they did align with the position papers released by the Bangon Pilipinas Party and pledged full support to its standard bearer, Villanueva. However, in the wake of the new media hype, which occurred through Aquino's (re)invention of reproductive health, they changed sides. Intercessors for the Philippines issued an anti-reproductive health manifesto that urged the government not to push the bill through. Invoking phrases such as the "sanctity of marriage" and "freedom of religion," the manifesto warned that the new law would be a gateway to abortion, divorce, and same-sex marriage, and that this would harm "the religious identity of the Philippines." 53 Thus, practically, Intercessors for the Philippines aligned with the Catholic discourse. Yet they still allowed contraceptives such as condoms, as long as they were used by married couples, which made them appealing to Catholic middle-class people (even though the latter would keep decisions like these rather private). This shift allowed the leaders of Intercessors for the Philippines to emancipate themselves from the two-time presidential loser Villanueva and to present themselves as sensitive to the loopholes leading toward legalization of abortion they thought they detected in the reproductive health bill. It also allowed them to gain more popularity among Catholic constituencies as they adapted a rhetoric that was conservative and yet allowed for a less conservative practice than that promoted in the official teaching of the Catholic Bishops' Conference of the Philippines. In fact, the manifesto was actively disseminated by Catholic antireproductive health campaigners, thus providing Intercessors for the Philippines excellent publicity.

In a similar way, the Movement for National Transformation also changed sides in the debate on reproductive health. From $20 \mathrm{I} 2$ onward its seminars, "Christian Politics," whose primary public was Pentecostal pastors, included a large section on anti-reproductive health. This, at first glance, seemed to be in accordance with the officially morally conservative Catholic mainstream. It warned that the reproductive health law, especially its sections on mandatory sex-education in school, would lead society to sin and self-destruction. For example, the Kikay Kit, a sex-education pamphlet distributed by the United States Agency for International Development, was cited in order

and how this relates to ethical issues, he would be in favor of encouraging couples to use it. Thus, he steered a middle way that prevented him from alienating his conservative religious core-public. In the same diplomatic way, he admitted that "grade $5 \ldots$ is too young [for sex education]," yet in stark contrast to other candidates he left it up to a democratic debate to decide: "congress should study carefully what's the best age for young people to receive sex education.” Philippine Center for Population \& Development and Daily Inquirer, "News-How They Stand on Population," Philippine Center for Population \& Development (blog), June 3, 201०, http:/l www.pcpd.ph/index.php/news/how-they-stand-on-population.

53 The manifesto also included such apodictic statements as ' $t$ t]eaching children sex is naturally ... vested on the parents and it is not in keeping with ... constitutional principles for the State to teach the subject to young children within the Grade 5 Level" and a rejection of the intrauterine device as an abortifacient. Daniel A. Balais and Intercessors for the Philippines, "A Manifesto: Intercessors for the Philippines' (IFP) Stand on the Rh Bill," 2OI 2, http://docs.google.com/viewer?a=v\&pid=forums\&srcid=MDIyNjYwNjAyMzkwNzM4MDIxNDEBMTM ${ }_{2} \mathrm{ODgzaz}_{2} \mathrm{NzM}_{5} \mathrm{MTU}_{0} \mathrm{NzA}_{3} \mathrm{MzQBcFYyQTVMTzU}_{1}$ YllKATQBAXYy (website no longer available). 
to warn that reproductive health would foster a culture of selfishness, particularly a section of the pamphlet that explained "masturbation" as "a way of knowing our bodies and release tension." 54 This was read through the lens of a popular Augustinian theology of sin, where selfishness was viewed as the metaphysical root cause of all evil on earth and as the earmark of the civitas diaboli (kingdom of the devil). However, contrary to Intercessors for the Philippines and to the Catholic mainstream, the Movement for National Transformation conceived selfishness as greed, which was understood in a framework of Marxist social analysis. As was the case with the former Pentecostals, the critique of reproductive health served to politically mobilize churches. Given the constituency, it was necessary to articulate the political in the Pentecostal idiom. The powers to be challenged were called "Satan ... and his sons." 55 In contrast to the meaning of this phrase that one might expect from the current state of the research on Filipino Pentecostalism, however, the sons of Satan were not the unbelievers. ${ }^{6}$ Rather, the sons of Satan were "the capitalist[s]" engaged in "systemic exploitation" along with multinationals: "Foreign Interest, Big Landlords, Big Businessmen, Key Government/ Military Officials, Judges [determined to] sustain their political power base." 57

Quoting Mao Tse-tung, the 20I 2 Movement for National Transformation seminar explained that effectively changing the political status quo required Pentecostals to "build a political machinery" and "a mass line." With regard to the machinery, the seminar recommended aligning with opposition parties at the local level..$^{8}$ With regard to the mass line, 59 the Movement for National Transformation recommended forming "a synthesis of the desires and aspirations of the people" to engage in "good propaganda ... [that] is close to the hearts of the people ... [to be] mobilized." ${ }^{60}$ To reach this aim it was necessary to employ the morally conservative discourse of the majority-population influenced by the Catholic hierarchy, in spite of inner-Catholic contestation. ${ }^{61}$

With this shift from pro- to anti-reproductive health, the grassroots organization Movement for National Transformation aimed at emancipating itself from Villanueva and tried to launch a

54 Department of Education [Philippines], “Kikay Kit: Kaalama’t Impormasyon Sa Katawa't Kalusugan Nating Youth" [Vanity kit: Wise information about the body for young people] (no date).

55 Wyden King and NFS/M4NT, "Kingdom Politics IoI," February 5, 20I3, I7 (author's private collection). This is part of the informally published materials circulated among the churches I studied. These include PowerPoint presentations and teaching materials for courses titled "Kingdom Politics IoI," "Politics IoI," "Christian Politics," and the like, organized by the Movement for National Transformation, founded by Wyden King.

56 Recall that recent studies portray Pentecostals as "religiously intolerant," escapist "populists," who are indifferent to "issues of social justice." See, for example, Kessler and Rüland, Give Jesus a Hand!, I I 5 , I 96.

57 King and NFS/M4NT, "Kingdom Politics IoI," I7.

58 "Build[ing] the Machinery" involved building up a "Mass Base in Urban and Rural Communities," forming "tactic and strategic alliances," determining the number of "command votes multiplied by cost of a vote," and asking local politicians "for strategic positions ... in appointed positions." King and NFS/M4NT, "Kingdom Politics IOI,” $62,75,82-83,88,90$.

59 Mao Tse-tung used the concept of "mass line" to concretize the idea that a revolution must be for and from the people. Thus, the mobilization of the people (the masses) had to occur in a way that considered not just the needs and interests of the common people but also their mentality. This implied a three-stage process: first, studying the masses taking their unsystematic and scattered ideas and synthesizing them into systematic, concentrated ideas; second, going back to the masses, explaining and propagating the concentrated ideas until they embrace them as their own; and third, putting the concentrated ideas into action. Stuart R. Schram, "Mao Tse-Tung's Thought from 1949 to 1976 ," in The Cambridge History of China, ed. John K. Fairbank and Roderick MacFarquhar, vol. I5, The People's Republic, Part 2, Revolutions within the Chinese Revolution, I966-1982 (Cambridge: Cambridge University Press, I99I), I-IO4, at 4.

60 King and NFS/M4NT, "Kingdom Politics IoI," 44, 4I.

6I Leviste, "In the Name of Fathers," I6, 29, 32-33. 
staunch bottom-up approach that would not focus on filing its own candidate and on the shortlived campaign period, but on long term political education at the grassroots (that is, the mass-line strategy mentioned above). After the 20 Io defeat, the Movement for National Transformation's founder, Wyden King, a former cadre of the Communist Party of the Philippines, became critical of Villanueva's top-down approach. Reproductive health was a means to articulate an alternative, on the one hand, to the radical left that, according to the Movement for National Transformation, had opted for violence and operated with anachronistic Cold War paradigms. On the other hand, Movement for National Transformation presented itself as an alternative to the parliamentary approach of Villanueva, who although striving for social reforms was perceived as being shortsighted and having been co-opted by the government.

\section{HEGEMONY, POPULISM, AND EMPTY SIGNIFIERS}

What implications can be drawn from this data for the study of religion and its entanglement with politics and law-making in the Philippines? As An-Na'im has argued, "it is never about law and religion in the abstract, but always about a specific view of particular legal and religious traditions as viewed through the inherently limited experience of human beings." ${ }^{62}$ Thus, we need to examine religious actors by studying their concrete context. Against the current state of the research, this requires a robust and more nuanced concept of populism. This in turn demands a theoretical and epistemological framework robust enough to assess the studied people's articulations within the hegemonic struggles in which they occur.

\section{Hegemony and Populism}

Hegemony, as Antonio Gramsci puts it, is a form of dominance which rather than being based on coercion depends on its appeal to what is "accept[ed] ... as normal" (or to the plausibility of normality) to the people being ruled. ${ }^{63}$ Building on Gramsci, Ernesto Laclau argues that hegemony is "a political type of relation," but not a "determinable location within a topography of the social. In any given social formation, there can be a variety of hegemonic nodal points." ${ }_{44}$ With his emphasis on "nodal points" Laclau parts ways with studies that understand hegemony as an uncontested absolute dominance. This helps to understand the following paradox: on the one hand the Catholic hierarchy in the Philippines is able to exert social control by organizing a widespread consent on moral issues surrounding reproductive health, even among those who while subscribing to the hierarchy's public rhetoric, act differently in their private lives. ${ }^{65}$ On the other hand, the hierarchy is contested from within and from outside Catholicism so that it struggles to maintain said control.

Furthermore, Laclau argues that a "hegemonic formation also embraces what opposes it, insofar as the opposing force accepts the system of basic articulations of that formation as something it

62 Abdullahi A. An-Na'im, "Complementary, Not Competing Claims of Law and Religion: An Islamic Perspective," Pepperdine Law Review 39, no. 5 (2013): I 23 I-56, at I 232.

63 Asli Daldal, "Power and Ideology in Michel Foucault and Antonio Gramsci: A Comparative Analysis," Review of History and Political Science 2, no. 2 (2014): I49-67, at I 53, I 55-56; Thomas R. Bates, "Gramsci and the Theory of Hegemony," Journal of the History of Ideas 36, no. 2 (I975): 35 I-66, at 353, 356.

64 Ernesto Laclau and Chantal Mouffe, Hegemony and Socialist Strategy: Towards a Radical Democratic Politics, 2nd ed. (London: Verso, 200I), I39, see also 69.

65 Leviste, "In the Name of Fathers," 34; Jayeel S. Cornelio, Being Catholic in the Contemporary Philippines: Young People Reinterpreting Religion (Abingdon: Routledge, 2016), I07-09. 
negates." ${ }^{66}$ Against this background, and as will become clear in the following paragraphs, Laclau conceptualizes populism in a different way than most scholars of populism and recent studies on Pentecostalism in the Philippines do. ${ }^{67}$ The latter understand populism as a "type of movement" or a "political style" that rests on a specific "set of mobilization techniques," such as emphasizing the primacy of the people to be restored, appealing to "the common man," providing "simple explanations" and remedies along with stark polarizations; and combine it with ideological elements, such as antidemocratic authoritarianism, religious intolerance, and indifference toward questions of social justice. ${ }^{68}$ Laclau, instead, conceptualizes populism as a "political logic," arguing that "[ $t]$ here is no political intervention which is not populistic to some extent" 69 because any political intervention rests on the "logics of equivalence and difference" operative in any endeavor that aims at successful mobilization. $7^{\circ}$ This makes clear why Pentecostal groups who offered themselves as an alternative to what they polemically called the ruling Catholic elite could neither ignore reproductive health nor establish a discourse that was absolutely different from that of the hierarchy. ${ }^{7}$

In order to participate in the public discourse about the future of the country, Pentecostal actors, just like President Aquino, had to mobilize differing individuals and groups into a political bloc. Forming a bloc required a signifying element under which a maximum of different positions and demands could be subsumed. Yet signifying elements are overdetermined; they can even mean contradictory things to different people. As I have shown, terms such as pro-poor or social justice could signify the positions of President Aquino, presidential candidate Villanueva, and the Catholic hierarchy, even though the agendas of these actors differed. Yet these signifiers are meaningful to people even if the link between signifier and signified is precarious, as is evident in the discussion about the break within Villanueva's Pentecostal camp. How can we theorize this instability of meaning and its effects on the mobilization of people, along with their attitudes toward the implementation of a specific law?

\section{Empty Signifiers}

The concept of the "empty signifier" is useful here. For Laclau, an empty signifier is one that is made out of positive and negative chains of equivalence and difference that at the same time are held together by the same empty signifier. Thus, the signifier is not empty in the sense that it has no meaning whatsoever, but in the sense that it is overdetermined and therefore available to a plurality of meanings. Particular positions use the signifier to identify with a particular struggle on the promise that it will meet the totality of their particular interests. $7^{2}$ As such, an empty signifier identifies anything that threatens this struggle as a clear antagonist and produces a "we" - an operation that Laclau calls "constructing the "people." 73 In this way, the Pentecostals, trying to simplify the

66 Laclau and Mouffe, Hegemony and Socialist Strategy, I39.

67 See Karin Priester, "Definitionen und Typologien des Populismus" [Definitions and Typologies of Populism], Soziale Welt 62, no. 2 (201 I): I85-98, at 193-95; Kessler and Rüland, Give Jesus a Hand!, I4-20.

68 Ernesto Laclau, On Populist Reason (London: Verso, 2007), I I 7; Kessler and Rüland, Give Jesus a Hand!, I4-29, I80-I97.

69 Laclau, On Populist Reason, I I7, I64

70 Laclau, On Populist Reason, II7, 200; Benjamin Moffitt and Simon Tormey, "Rethinking Populism: Politics, Mediatisation and Political Style," Political Studies 62, no. 2 (2014): 38 I-97, at 384.

7 I "The place of the negation is defined by the internal parameters of the formation itself." Laclau and Mouffe, Hegemony and Socialist Strategy, I39.

72 Laclau, On Populist Reason, 69-72, IOI-I7; see also Ernesto Laclau, Emancipation(s) (London: Verso, I996), $36-46$.

73 Laclau, On Populist Reason, 65. 
background and prospective effects of the reproductive health policy by staging themselves against an "enemy" (in this case the "ruling Catholic elite"), followed the same logic as that of President Aquino or any other group. Reproductive health could make sense for Pentecostals around Villanueva only as long it stood for a positive chain of equivalence in which terms like focus on the spiritual and prayer were made equivalent with a pro-poor politics of transformation, righteousness, and the like vis-à-vis a negative chain in which materialism and liberalism were made equivalent with politics that favored elites and multinationals, abortion, anti-Filipino, anti-God, and the like and served to mark an outside (or the characteristics of those others from which the Pentecostals wanted to differ radically). This was the same with Aquino, as my discussion of his "Responsible Parenthood" showed: reproductive health could make sense for his intended public only as long as it stood for a positive chain of equivalence that connected pro-poor with pro-life vis-à-vis a negative chain that equated unconstitutional, anti-Catholic, and abortion and thus appealed to the common people and created two collective identities essentially defined by the said elements of the chains-a common we (or us) against the others (or them).

\section{Discourse}

To further explicate this, it is useful to discuss the notion of discourse and its epistemological implications. Following Foucault and poststructuralist semiotics, Laclau operates with an inclusive concept of discourse that is not limited to speech but views discourse as the ensemble of words, action, institutions, and rules that shape the way the studied people think, speak, and act. The possibility that a term such as pro-poor can mean (signify) even contradicting things to different people is what Laclau attributes to the infinite "play of differences" 74 that ensures the radical openness of any signification system. From this perspective "there are no positive terms in language, only differencessomething is what it is only through its differential relations to something else." 75 A word or action is what it is only through its being different from other possible actions and signifying elements (words or actions). ${ }^{76}$ Put differently, there is no fixed, naturally given external order (an outside) from which signifying elements draw their meaning.

But, then, how is communication (words and actions) possible? In the absence of a "transcendental signified," meaning is possible only if the "infinite play" is given a limit, if the "floating" of the elements is "arrested." 77 If "there is no beyond the play of differences, no ground which would a priori privilege some elements of the whole over the others," the fact that certain elements acquire meaningfulness, "has to be explained by the play of differences as such." 78 In other words, the limit that arrests the "infinite play" must come from within the "purely differential ensemble." 79 From this Laclau concludes that the only possible way of having an external order (an outside) that limits the floating and arrests the infinite play is that the limit principle is not simply a neutral or external element (there is no objective or natural true/false in the question about what social justice is). Rather it is the element that is excluded from within the signification system that allows the system to arrest the infinite play of differences; it is "something that the totality of elements expels from itself in order to constitute itself." $8 \circ$ It was through the demonization of

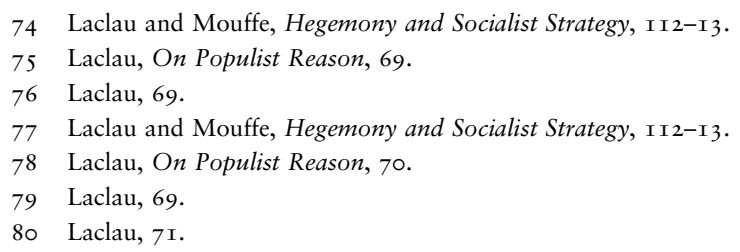


an "other" (Catholic elites, neocolonial imperialists, or anti-Filipino abortion promoters) that the studied groups (for example, Pentecostals aligned with Villanueva, Aquino's political followers) reached a sense of their own cohesion despite their heterogeneity with regard to individual interests and aspirations. ${ }^{8 \mathrm{I}}$ Thus, meaning is produced when one particular element is made to embody the radical differentiality and therefore comes to represent the totality of the differential system.

Against this epistemological background, the Pentecostals' articulations about reproductive health (that draw on rhetorics such as "sons of Satan" and the vision of a better Philippines) followed the logic of antagonism that constitutes any form of mobilization, which is also an act of (collective) identity making. From within the different positions of the people to be mobilized one difference emerged as a master signifier which than constituted a cohesive, collective body with a common identity. This is what Laclau calls a "radical investment": "vis-à-vis the excluded element, all other differences are equivalent to each other-equivalent in their common rejection of the excluded identity." 82

Yet if the elements became absolutely equal, they would lose their identity and thus cease to mean anything. Therefore, the "logics of equivalence" is co-constituted by a "logics of difference," which makes the identity of the signifying elements and accordingly their meaning highly unstable (hence, the overdetermination of signifiers and the precariousness of meaning.). ${ }^{83}$ Given that all discursive elements are equally different, there is no necessary reason why one specific element is expelled instead of another. The radical investment is therefore always contingent. However, contingency does not mean arbitrariness in a relativistic sense as any investment does not occur in a social vacuum: a signifier ceases to be such if it is isolated from those to whom it means something. ${ }^{84}$ Thus, according to Laclau, if signifiers mean anything, they do so as a result of a hegemonic act. ${ }^{85}$ If certain signifiers seem to have an unquestioned meaning or to be self-evident, it is because the social practices responsible for the making of such signifiers have been either concealed or forgotten (along with groups of people who have been antagonistic to them). This is what Laclau calls processes of "sedimentation." 86 In corroboration with exclusions of various kinds (both of antagonistic claims and people) they form "the social": the fabric of meanings which are regarded as natural givens and upon on which politics (that is, understood as the act of domesticating enmities) draws until the meanings and with them the powers that be are contested. ${ }^{87}$ Thus, the moment of contestation is when the political emerges as a field of antagonism. ${ }^{88}$ In order to be effective, however, any such contestation requires a counter-hegemonic formation that follows the same logic: it requires that from the plentitude of antagonisms among those who form the counter-hegemonic bloc one is expelled and articulated in a way that reduces the

8 I Laclau, 7I.

82 Laclau, 7I.

83 Laclau and Mouffe, Hegemony and Socialist Strategy, I29.

84 Oliver Marchart, Die Politische Differenz: Zum Denken des Politischen bei Nancy, Lefort, Badiou, Laclau und Agamben [The Political Difference: Thinking the political in Nancy, Lefort, Badiou, Laclau and Agamben] (Berlin: Suhrkamp, 20I0), I9I-92; Michael Bergunder, "What Is Religion? The Unexplained Subject Matter of Religious Studies," Method and Theory in the Study of Religion 26, no. 3 (2014): 246-286, at 263.

85 Laclau, On Populist Reason, 70, IOI-I7.

86 Ernesto Laclau, New Reflections on the Revolution of Our Time (London: Verso, 1990), 34; Lynn Worsham and Gary A. Olson, "Hegemony and the Future of Democracy: Ernesto Laclau's Political Philosophy," in Race, Rhetoric, and the Postcolonial, ed. Gary A. Olson and Lynn Worsham (Albany: State University of New York Press, I999), I46.

87 Laclau, New Reflections, 35; see also Marchart, Die Politische Differenz, 206.

88 Laclau, "Hegemony and the Future," I46. 
different antagonistic positions found within the camp perceived as representing the status quo to a singularity. At the same time, this operation converts the differences among those mobilized to form a counter-hegemonic bloc into a chain of equivalences. Thus, the signifier is articulated in the form of advocacy, addressing the demands of the largest possible collective entity, for example, the nation's poverty crisis, or inclusive economic growth articulated with reference to God and life (as in pro-life).

To recapitulate, the making of an "empty signifier" allowed a plurality of particular positions to identify with a single struggle on the promise that it would meet the totality of their particular demands. ${ }^{89}$ As such, reproductive health created an identity with a common struggle and identified anything that threatened this struggle as a clear antagonist. This facilitated the construction of a "people" - a "we" against a "them." 90 Against this background, any articulation of the political, if it is supposed to be effective, follows the "logics of equivalence" and "of difference" and "construct $[\mathrm{s}]$... the "people"" on the promise of a "fullness" that can never be achieved because it would result in the loss of the particular identity of those who form the people. ${ }^{91}$

\section{Summary}

In the light of this conceptual framework, which takes seriously that signifiers (words or actions) do not have any fixed meaning but that meaning is both a discursive operation and a hegemonic act resting on the logics of equivalence and on the production of empty signifiers that in turn constitute precarious identities, and contrary to the way newer studies depict the movement, ${ }^{92}$ the Pentecostals were no more nor less populist than were any other political players, including President Aquino and his party. In Aquino's "Responsible Parenthood," reproductive health could be meaningful (make sense) for his intended public only as long as it stood for a positive and a negative chain of equivalence. To mobilize voters, Aquino had to emphasize the primacy of the people against those liberal elites that were corrupt, anti-Filipino, and anti-family; he had to appeal to the common people, providing simple explanations and remedies to poverty, along with stark polarizations. Aquino equaled pro-poor with pro-life and similar stances vis-à-vis a negative chain of equivalences that equaled unconstitutional, anti-Catholic, and abortion, creating a collective we identity against a them identity. Likewise, Pentecostals articulated pro-life and anti-life in relation to anti-Filipino, anti-God, and anti-people or in relation to anti-poverty or moral health of the nation as a catalyst for inclusive growth and development-nodal points that then became elements of larger chains of equivalence that constituted the empty signifier reproductive health. Reproductive health, in turn was a "name" that served to "construct[] a people" around a single struggle that would solve the nation's crisis. ${ }^{3}$ In employing this "name," Pentecostals refused to accept that their participation in the democratic process be limited only to the ballot box. If Pentecostals drew on articulations that appeared "religious" and "conservative," it was because such an idiom was highly plausible among their targeted audience as a consequence of sedimentation processes in which the Catholic hierarchy has played a dominant role acquiring a hegemonic role.

89 Laclau, On Populist Reason, 69-72, IOI-I7; see also Laclau, Emancipation(s), 36-46.

90 Laclau, On Populist Reason, 65.

9I Laclau, 70, 95, $23 \mathrm{I}$.

92 Kessler and Rüland, Give Jesus a Hand!, I80-97.

93 Laclau, On Populist Reason, I 53, 23 I. 
This applies also to the term religion, which then becomes the reference for the studies I presented in my introduction to this article. Against this background it is misleading to view religion as having a certain ontological status, as it is the case in the approaches that define religion as sphere of human being sui generis or as a mere belief system or worldview that helps to cope with the "insecurities" brought along by "societal transformations." 94 Rather, religion is to be viewed as a "name" that serves as a marker of identity whenever people make reference to it. Referring to keywords and narratives commonly perceived as religious was a way to position oneself in the debates regarding the future of the country in a social context marked by inequalities and power asymmetries. 95 Yet, the chains of equivalence and difference produced by these signifiers were precarious, given the differences of interests found among the Pentecostals and their allies. As far as the Evangelical Pentecostals were concerned, this led to an estrangement even between Villanueva, Intercessors for the Philippines, and the Movement for National Transformation. If scholarship focuses on such articulations as "we just pray," "sin," and "sons of Satan" and glosses over the antagonisms embedded in hegemonic dynamics, it can only dub Pentecostalism as otherworldly oriented or as reactionary "religious populism." This fails to acknowledge that any politics (that is, any formation that maintains or challenges hegemonic players) rests on a populist logic if it has to be successful in maintaining or challenging hegemonic players. Furthermore, it virtually denies large parts of the population in the Philippines the right to participate in the political debate beyond the ballot box..$^{6}$

\section{CONCLUSION}

What implications can be drawn from this discussion for the study of religion and politics-including lawmaking - in general? Recent studies that explain Pentecostalism's success by describing the movement as religious populism operate with too simplistic a concept of populism and fail to see Pentecostalism's complex relationship to the political. This will be the case as long as populism is understood as a specific political style and as long as references to God, sin, sons of Satan, and the like are viewed as a proof of religious intolerance, an intrinsic hostility to democracy, and indifference to issues of social justice. Not only are Pentecostals divided in the same ways that the larger public itself is, but the same antagonisms running through the public sphere also polarize the Pentecostal movement. The seemingly escapist rhetoric of intercession ("we just pray"), priority of scriptures, Satan, sin, and the like are a political gesture by which Pentecostals mark a difference from established churches and leftist groups. Nevertheless, under this surface, Pentecostals do engage with issues of social justice and the need to forge interreligious alliances to achieve structural change-and they do so in a way that is neither more nor less populist than do other groups or political parties, because this engagement occurs vis-à-vis concrete antagonistic struggles that require the "construction of a people" if hegemony has to be maintained or challenged.

94 Kessler and Rüland, Give Jesus a Hand!, I 53, 9-I 4.

95 See Bergunder, "What Is Religion?"

96 Or it imposes on them to "translate" their discourse into to the language of secularism, presupposing "the secular" to be exterior to "the religious" as does Jürgen Habermas, Zwischen Naturalismus und Religion: Philosophische Aufsätze [Between naturalism and religion: Philosophical essays] (Frankfurt: Suhrkamp, 2005), I 19-54. For a critique, see the works of Talal Asad and Saba Mahmood on the elitism and Eurocentrism of such a concept of the secular. Talal Asad, Genealogies of Religion: Discipline and Reasons of Power in Christianity and Islam (Baltimore: Johns Hopkins University Press, I993); Talal Asad, Formations of the Secular: Christianity, Islam, Modernity (Stanford: Stanford University Press, 2003); Saba Mahmood, Religious Difference in a Secular Age: A Minority Report (Princeton: Princeton University Press, 2016). For an alternative approach, see Bergunder, "What Is Religion?" 
If this has gone unnoticed by scholars, we should ask whether this is not a (conscious or unconscious) perpetuation of (neo)colonial structures that calls for a critique of its epistemic structures (categories and presuppositions) that call for a "decolonization." 97 Put differently, we should investigate for the conditions and limits of the epistemological and interpretative framework responsible for these blind spots - and what interests they eventually serve. $9^{8}$ In the wake of the secularization thesis, political and social studies have long looked at religion as something rather irrational and treated religious actors with an arrogance that lends to an implicit if masqueraded Eurocentrism.99 This applies also to the thesis of "Pentecostalism as religious populism," as it rests on an essentialist definition of religion which reduces the latter to a belief system that helps crisis-affected people to cope with the "insecurities" brought forth by "societal transformation." Iо० Therefore, if religion is not to become an instrument of escapist ideology and deception, it has to be "translated" in the allegedly secular idiom of politics. ${ }^{\text {IOI }}$ If scholarship does not account for the plausibility of discourses on government rule, justice, and rights found on the ground-or if it does so with a preconceived essentialist concept of religion - it will fail to acknowledge the agency of the people studied. This eventually amounts to a legitimization of dysfunctional democracies and serves the interest of an elite whose self-preservation is based on the exclusion of the larger parts of society from the discourse on government and legislation. In contrast, the approach I have argued for demands a thoroughgoing genealogical contextualization that looks past the prima facie rhetoric of "we just pray."

This approach avoids the temptation of considering those being studied as simpleminded masses who are so easily deceived that their active role in discussions on how to rule the country should be restricted. This approach, therefore, may promote more conducive debate on how policies can be formulated in a way that fosters equality, sustainable justice, and peace built on the base of what is plausible for the people concerned.

\section{ACKNOWLEDGMENTS}

This article is a product of a visiting fellowship at the Center for the Study of Law and Religion, Emory University funded by the Karl Schlecht Stipends for the Global Network of Research Centers for Theology, Religious and Christian Studies in the winter term 2017. I am indebted to Silas Allard, Rafael Domingo, and John Witte for critical remarks on an earlier version of this article presented at the Center for the Study of Law and Religion in November 2017. I also thank Michael Bergunder and the two anonymous reviewers, as well as Carolin Scheuffele, Dimitry Okopiridze, Jessica Albrecht, and Martina Echeverria, for helpful comments on previous drafts.

97 An-Na'im, "Decolonizing Human Rights."

98 Talal Asad, Wendy Brown, Judith Butler, and Saba Mahmood, "Preface, 2013," in Is Critique Secular? Blasphemy, Injury, and Free Speech, ed. Talal Asad et al. (New York: Fordham University Press, 20I3), vii-xx, at xvi.

99 Frank Neubert, Die Diskursive Konstitution von Religion [The discursive constitution of religion] (Wiesbaden: Springer VS, 2016), II6-20.

Ioo Kessler and Rüland, Give Jesus a Hand!, I 53.

IOI Jürgen Habermas, "Glauben und Wissen-Dankesrede" [Belief and knowledge-Acceptance Speech] in Friedenspreis des Deutschen Buchhandels [Peace Award of the German Book Trade] (Berlin: Börsenverein des Deutschen Buchhandels, 200I), 9-I 5, at I3. 